\title{
PENGEMBANGAN RTH SEMPADAN SUNGAI CISADANE SEBAGAI SALAH SATU ATRAKSI WISATA PADA KAMPUNG EKOWISATA KERANGGAN
}

\author{
Kusriantari Fenny $\mathrm{A}^{1)}$, Refranisa ${ }^{1)}$, Abi Maulana Hakim²) \\ 1)Program Studi Arsitektur, Institut Teknologi Indonesia, Tangerang Selatan, Banten, Indonesia \\ ${ }^{3)}$ Program Studi Teknik Sipil, Institut Teknologi Indonesia, Tangerang Selatan, Banten, Indonesia \\ Corresponding author : Kusriantari Fenny A \\ E-mail : fenny.aprillia@iti.ac.id
}

Diterima 05 Oktober 2020, Direvisi 20 Oktober 2020, Disetujui 21 Oktober 2020

\begin{abstract}
ABSTRAK
Peristiwa banjir Sungai Cisadane yang terjadi pada tahun 2014 berimbas pada menurunya minat daya tarik masyarakat untuk mengunjungi Kampung Ekowisata Keranggan, dikarenakan rusaknya sarana dan prasarana di sempadan Sungai Cisadane. Masyarakat berharap adanya sentuhan dari segi desain untuk meningkatkan citra pada Kampung Ekowisata Keranggan khususnya pada atraksi memancing ikan sebagai daya tarik utama agar menarik minat pengunjung untuk datang. Tujuan abdimas ini adalah membangkitkan atraksi wisata Kampung Ekowisata Keranggan dengan cara merancang spot pemancingan ikan. Mitra abdimas adalah warga Kampung Ekowisata Keranggan RW 05 yang berjumlah 100 kk. Untuk mendapatkan hasil rancangan yang sesuai dengan karakter dan kebutuhan, maka dimulai dengan survei lapangan/lokasi untuk mengenali dan memahami kondisi fisik maupun non fisik eksisting. Survei tersebut dilakukan dengan wawancara, pengamatan, pengukuran, pemotretan, penggambaran yang dilakukan secara terstruktur dengan masyarakat dan komunitas sadar wisata kampung Keranggan. Hasil dari survei kemudian dianalisis untuk mendapatkan konsep perencanaan dan perancangan spot pemancingan ikan yang fungsional dan estetis bagi Kampung Ekowisata Kranggan. Luaran abdimas berupa dokumen gambar rancangan serta evaluasi dari kegiatan abdimas ini adalah berupa tanggapan perwakilan masyarakat Kampung Ekowisata Keranggan terhadap desain spot pemancingan.
\end{abstract}

Kata kunci: ekowisata; perencanaan; perancangan; atraksi wisata; spot pemancingan

\begin{abstract}
Cisadane River Flood that happen in 2014 had an effect to decreasing the appeal of society interest to visit Keranggan Ecotourism, because of the damage facilities and infrastructure at Cisadane border. The society hope any design planning to increase Keranggan Ecotourism image especially at fishing attraction as the main attraction for visitor to visit. The purpose of this society service is to increase tourism attraction at Keranggan Ecotourism by designing fishing spot area. Partner of this society service is Keranggan Ecotourism society RW 05 numbering of 100 family head. To obtain design result that suitable to the character and needs, therefore it starts with site survey to identify and perceive physical and unphysical existing condition. Survey is conducted by interview, observation, measurement, photograph, and sketch that be done in structured with society and tourism community of Keranggan Village. The result of the survey then analyzed to get planning and designing concept of fishing spot area which is functional and aesthetic for Keranggan Ecotourism. Output of this society service is design drawing document and the evaluation of this program is respons of Keranggan Ecotourism society representatives to design of fishing spot area.
\end{abstract}

Keywords: ecotourism; planning; designing; tourism attraction; fishing spot area

\section{PENDAHULUAN}

Wisata adalah kegiatan perjalanan yang dilakukan oleh seseorang atau sekelompok orang denganmengunjungi tempat tertentu untuk tujuan rekreasi, pengembangan pribadi, atau mempelajari keunikan daya tarik wisata yang dikunjungi dalam jangka waktu sementara (Undang- Undang Republik Indonesia Nomor 10.Tahun2009 Tentang
Kepariwisataan, 2009). Sedangkan ekowisata adalah perjalanan wisata yang bertanggung jawab terhadap kelestarian lingkungan dan kesejahteraan masyarakat setempat (Hijriati \& Mardiana, 2015). Kampung Keranggan merupakan salah satu kampung berbasis Ekowisata yang letaknya berada di Kelurahan Keranggan, Kecamatan Setu Kota Tangerang Selatan. Melalui konsep perencanaan 
Ekowisata Berbasis Masyarakat atau Community Based Ecotourism (CBE) Kampung Keranggan dinobatkan sebagai kawasan strategis pariwisata Kota Tangerang Selatan Banten (Dinas Pariwisata Kota Tangerang Selatan, 2019). Berbasis masyarakat yang dimaksud adalah dalam hal perencanaan dan pengembangan pariwisata terdapat keterlibatan dari masyarakat, hal ini bertujuan untuk mendukung keberhasilan pengembangan destinasi wisata tersebut (Aryunda, 2011). Kepariwisaatan berbasis ekowisata pada Kampung Keranggan terlihat pada potensi Kampung Keranggan yang memiliki dua aspek sumber daya wisata yaitu sumberdaya alami dan sumber daya budaya. Sumber daya alami mencakup keanekaragaman flora fauna pada kawasan tersebut, sedangkan sumberdaya budaya mencakup mata pencaharian, sistem religi, sistem kekerabatan dan kesenian yang tersebar. Sumber daya tersebut dapat dijadikan atraksi wisata. Atraksi wisata merupakan komponen utama yang ditawarkan dalam suatu objek wisata (Crouch dan Ritchie, 1999 dalam (Vengesayi, 2003). Keberadaan Kampung Keranggan berbasis Kampung ekowisata didukung dengan letaknya yang startegis karena berada disamping perisis Sungai Cisadane sehingga memiliki potensi panorama bentang alam dan obyek bentang alam yang dijadikan sebagai daya tarik pada atraksi wisata. Sungai Cisadane sebagai potensi utama memberikan banyak manfaat bagi masyarakat sekitar diantaranya sebagai peningkatan kegiatan ekowisata yang memanfaatkan fauna ikan dari Sungai Cisadane. Keanekaragaman jenis ikan yang melimpah yang berasal dari Sungai Cisadane menjadi potensi mata pencaharian dan kegiatan ekonomi bagi beberapa masyarakat sekitar sehingga terdapat beberapa masyarakat bergantung pada sungai tersebut. Berdasarkan data dari dinas pariwisata Kota Tangerang Selatan, warga di Kampung Keranggan yang berprofesi sebagai nelayan untuk mencari ikan di Sungai Cisadane sekitar 10\%. Para Nelayan yang memperoleh ikan, biasanya langsung menawarkan ikan hasil tangkapannya ke rumah makan atau kerumah rumah warga di sekitar untuk dikonsumsi secara pribadi. Ikan yang dihasilkan dari Sungai Cisadane merupakan jenis ikan air tawar yang memiliki keragaman cukup banyak terdiri dari tiga jenis yang dominan yaitu ikan baung, ikan tawes, dan ikan cere. Metode pencarian ikan oleh masyarakat sekitar dilakukan secara aman karena mengikuti peraturan dari pemerintah yaitu tidak menggunakan bom ikan, potasium dan strum.
Adapun potensi Sungai Cisadane sebagai sumberdaya alam bagi Kampung Ekowisata Keranggan diantaranya adalah sebagi atraksi kegiatan wisata yang dilakukan pada area sempadan sungai. Atraksi wisata alam yang ditawarkan oleh Kampung Ekowisata Keranggan yang memanfaatkan potensi Sungai Cisadane diantaranya adalah spot memancing ikan Cisadane, memasak ikan, night Cisadane fishing camp, jalur pengamatan burung, jalur pengamatan reptile dan amphibi, kawasan pertanian, river front, dll. Selanjutnya penggunaan sosial budaya di sekiatar sempadan Sungai Cisadane sebagai area berkumpul terutama pada sore hari karena terdapat beberapa saung yang didirkan oleh warga, aktivitas memancing, mandi dan banyak remaja yang bermain di Sungai Cisadane atau berenang. Salah satu atraksi wisata alam yang digemari adalah kegaiatan memancing ikan. Kegiatan memancing disekitar kawasan tersebut telah diakomodir dengan standar operasional prosedur yang disusun sesuai dengan nilai nilai ekowisata. Biasanya banyak masyarakat berdatangan untuk memancing sambil bersantai untuk menikmati suasana pada sore hari. Selain itu, perlu diadakan acara tahunan yang merupakan salah satu cara promosi agar Kampung Ekowisata Keranggan dapat berkembang. Dikarenakan special event merupakan salah satu faktor seseorang melakukan perjalanan wisata (Amalina, 2017). Masyarakat setempat memegang peranan yang sangat penting, baik sebagai pelaku usaha, tenaga kerja maupun sebagai tuan rumah dalam menyelenggarakan kegiatan kepariwisataan di suatu destinasi (Khotimah \& Wilopo, 2017).

Peristiwa banjir yang sempat terjadi pada tahun 2014 berimbas pada rusaknya sarana dan prasaran di pinggiran Sungai Cisadane, sehingga berimbas pada menurunya minat daya tarik masyarakat untuk mengunnjungi Kampung Ekowisata Keranggan. Pada kondisi sekarang ini, kondisi dipinggiran sekitar sungai sepi. Kegiatan atraksi wisatapun belum berjalan karena tidak adanya sarana fisik yang tersedia. Selain itu berimbas pula pada penurunan ekonomi warga sekitar yang biasanya berjualan disekitar area tersebut. Pada kondisi sekarang ini tepat bersebrangan dengan Kampung Keranggan terdapat developer yang melakukan pengembangan rumah modern, hal tesebut memicu ketakutan pada akan keberadaan lokasi Kampung Ekowisata yang semakin terdesak. Apabila dilihat secara visual terlihat kesenjangan penampilan citra antara Kampung Keranggan dengan Perumahan Modern yang bersebrangan seolah Kampung Keranggan 
menjadi kawasan yang tidak tertata. Masyarakat berharap adanya sentuhan dari segi desain untuk meningkatkan citra pada Kampung Keranggan, selain itu juga Kampung Keranggan yang telah dinyatakan sebagai kampung ekowisata karena ekosistem Sungai Cisadanenya, dapat sekaligus mendorong program konservasi sungai (Aulia \& Hakim, 2017). Selain meningkatkan citra kota, kegiatan konservasi melalui ekowisata memiliki manfaat ekonomi jangka panjang kepada masyarakat lokal (Wardhani, 2011).

Melihat fenomena tersebut, guna meningkatkan dan menjaga keberlanjutan atraksi wisata disekitar Sungai Cisadane pada Kampung Ekowisata Keranggan maka perlu adanya dukungan sarana fisik untuk menunjang kegiatan atraksi salah satunya pada kegiatan memancing yang sudah banyak dilakukan oleh warga sekitar. Tujuan abdimas ini adalah membangkitkan atraksi wisata Kampung Ekowisata Keranggan dengan cara merancang spot pemancingan ikan. Selain itu untuk meningkatkan citra Kampung Keranggan, desain spot pemancingan juga dapat mewadahi kegiatan ekonomi dan sosial budaya, dengan begitu diharapkan nantinya Kampung Ekowisata memiliki karakter yang bisa dilihat secara visual khususnya dari arah jalan utama Puspiptek-Cisauk, atau dari lokasi perumahan modern Kabupaten Tangerang dan berimbas pula pada naiknya citra Kampung Ekowisata Keranggan. Dengan dilakukannya perancangan spot pemancingan, diharapkan aksesibilitas dan amenitas juga akan tumbuh pada Kampung Ekowisata Keranggan. Atraksi, aksesibilitas, dan amenitas merupakan produk yang tidak dapat terpisahkan dalam pengembangan objek wisata (Abdulhaji \& Yusuf, 2016). Target luaran yang ingin dicapai adalah menghasilkan dokumen rancangan spot pemancingan Kampung Ekowisata Keranggan.

\section{METODE}

Kegiatan pengabdian masyarakat dilakukan di Kampus ITI dan Kampung Ekowisata Keranggan yang terletak di Kelurahan Keranggan, Kecamatan Setu Kota Tangerang Selatan, selama delapan bulan di tahun 2020. Waktu pelaksanaan adalah dimulai bulan Maret sampai Oktober 2020. Mitra dalam abdimas ini adalah warga Kampung Ekowisata Keranggan RW 05 yang berjumlah 100 kk. Sebagai informasi, kampus ITI telah menjadikan Kampung Keranggan sebagai kampung binaan dan telah beberapa kali menjadi obyek pengabdian masyarakat. Berikut adalah tahap-tahap dalam pelaksanaan pengabdian masyarakat ini: (a) Pertemuan dengan Dinas Pariwisata Kota Tangerang
Selatan beserta pemuda Kampung Keranggan. Hal ini bertujuan untuk menyatukan persepsi antara pemerintah kota, kampus ITI, beserta masyarakat Kampung Keranggan (gambar 1 dan gambar 2); (b) Pemilihan spot perancangan. Spot pemancingan merupakan spot terpilih dikarenakan kondisi eksisting masyarakat yang memiliki mata pencaharian sebagai nelayan dan gemar memancing; (c) Perumusan konsep perancangan. Pada tahap ini dilakukan diskusi terkait konsep desain spot pemancingan. Dalam melakukan perumusan konsep, diawali dengan penelusuran data eksisting, analisis, dan perumusan konsep perancangan; (d) Penyusunan gambar perancangan. Pada tahap ini dilakukan penyusunan gambar rancangan. (e) Sosialisasi terhadap perwakilan mayarakat Kampung Ekowisata Keranggan.

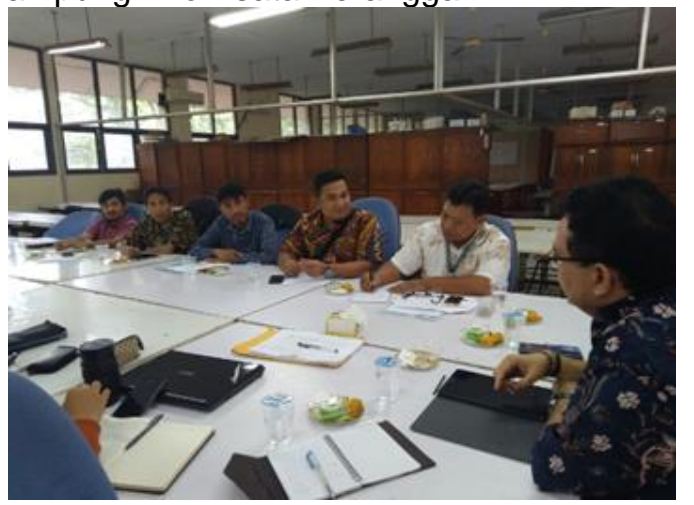

Gambar 1. Pertemuan dosen Prodi Arsitektur dengan Dinas Pariwisata dan pemuda Keranggan (Sumber: Dokumentasi Penulis)

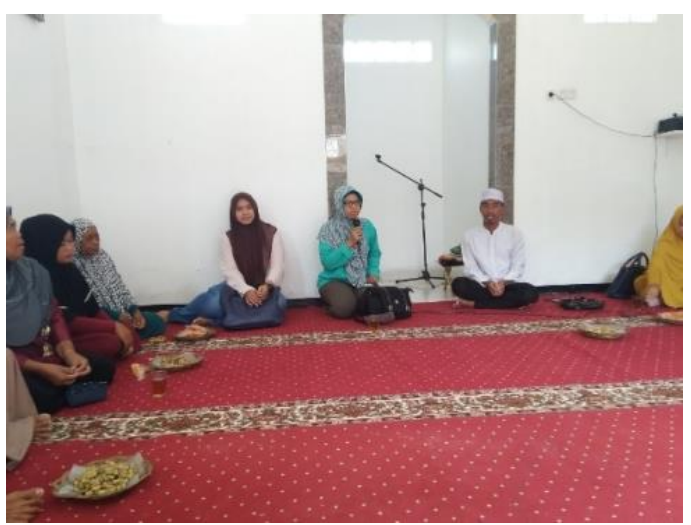

Gambar 2. Koordinasi dengan Warga Kampung Keranggan

(Sumber: Dokumentasi Penulis)

Hasil akhir dari pengabdian masyarakat ini adalah berupa dokumen gambar rancangan yang akan di sosialisasikan kepada perwakilan masyarakat Kampung Keranggan, metode evaluasi kegiatan abdimas ini adalah tanggapan dari perwakilan masyarakat terhadap dokumen gambar rancangan yang dipaparkan, apakah bisa 
diterima atau tidak.

\section{HASIL DAN PEMBAHASAN}

Pelaksanaan kegiatan Abdimas ini diawali dengan pengumpulan data yaitu dengan metode survey lapangan (gambar 3). Survey lapangan bertujuan untuk meninjau langsung tapak dari spot pemancingan yang akan didesain. Kegiatan yang dilakukan adalah pengukuran lapangan, dokumentasi, dan wawancara singkat terhadap beberapa warga yang gemar memancing. Selain dilakukan survey lapangan, pengumpulan data juga dilakukan dengan mencari jurnal atau dokumen terkait dengan perancangan spot pemancingan.

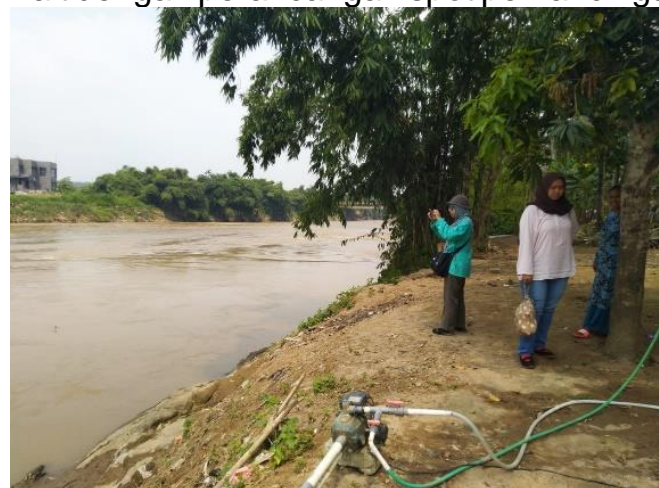

Gambar 3. Proses survey lapangan

(Sumber: Dokumentasi Penulis)

Setelah dilakukan pengumpulan data, proses selanjutnya adalah menganalisis, analisis dilakukan guna menentukan konsep perancangan yang tepat. Analisis terdiri dari analisis tapak, analisis pengguna dan aktifitas. Setelah proses analisis selesai dilakukan maka selanjutnya dilakukan perumusan konsep perancangan dan dituangkan dalam desain dan penyempurnaan desain untuk kebutuhan presentasi.

\section{Tinjauan Lokasi}

Kampung Keranggan terletak pada Kelurahan Keranggan, Kecamatan Setu, Kota Tangerang Selatan. Kampung ini berbatasan langsung dengan Sungai Cisadane.

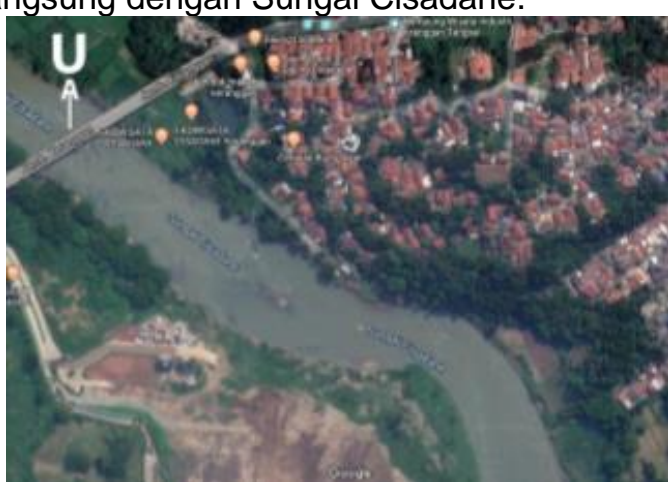

Gambar 4. Lokasi Kampung Keranggan (Sumber: Google Earth)

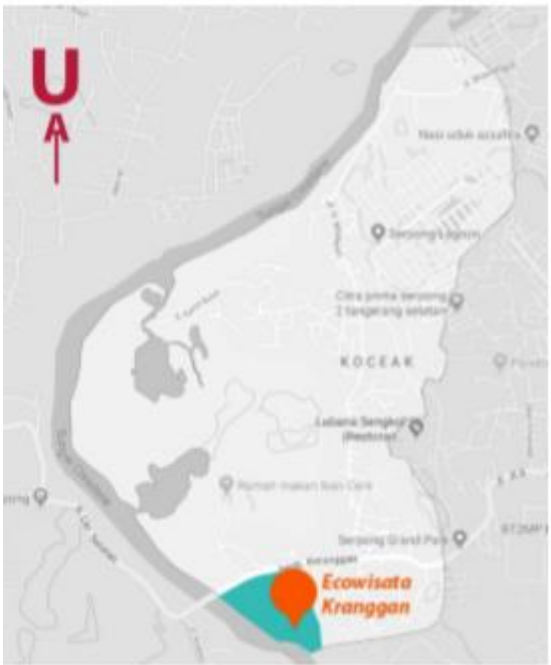

Gambar 5. Lokasi Kampung Keranggan (Sumber: Dinas Pariwisata Kota Tangsel)

Lokasi spot pemancingan dan atraksi wisata lainnya telah ditentukan oleh Dinas Pariwisata, yaitu tertera pada gambar 6 . Spot pemancingan terletak pada nomor 1. Gambar 7 menunjukkan lokasi dan ukuran tapak spot pemancingan.

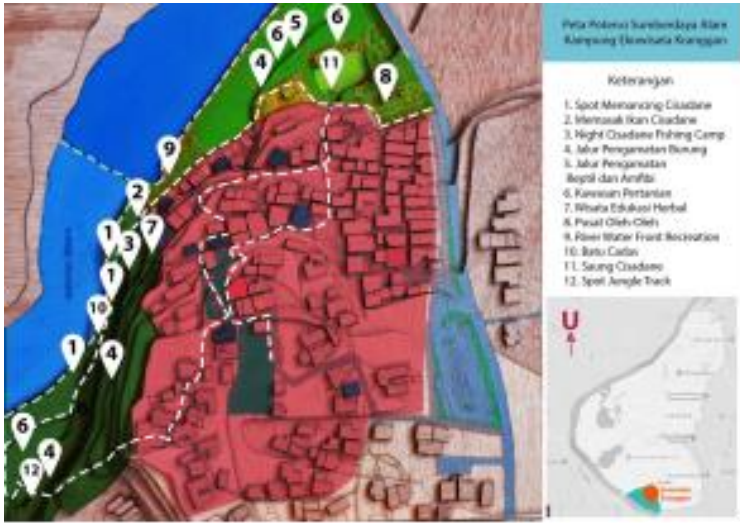

Gambar 6. Lokasi Spot Pemancingan (Sumber: Dinas Pariwisata Kota Tangsel)

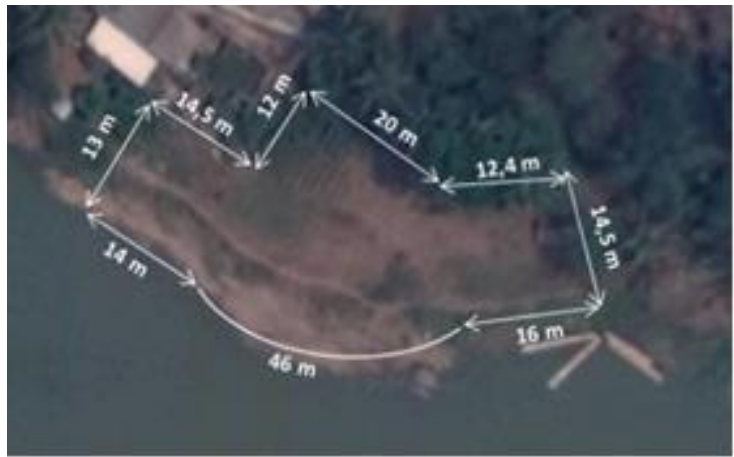

Gambar 7. Lokasi dan ukuran tapak (Sumber: Dinas Pariwisata Kota Tangsel)

\section{Konsep Perancangan \\ Konsep perancangan spot pemancingan yaitu mengedepankan keadaan}


eksisting dimana kontur bibir sungai tidak banyak diubah. Desain dibuat berundak-undak untuk mempertahankan kontur eksisting, sekaligus sebagai pengaman rumah warga ketika terjadi luapan air sungai. Selain itu bentuk tanah yang agak menjorok ke sungai tetap dipertahankan dan dimanfaatkan sebagai area utama yaitu spot pemancingan. Sebagai pengaman, tanah yang menjorok diperkuat dengan dinding beton supaya tidak tergerus arus air sungai. Vegetasi eksisting tetap dipertahankan terutama yang dekat dengan bibir sungai, namun terdapat penambahan vegetasi lain untuk tujuan estetika.

\section{Hasil Desain}

Berikut beberapa gambaran hasil desain area spot pemancingan dari berbagai macam view.

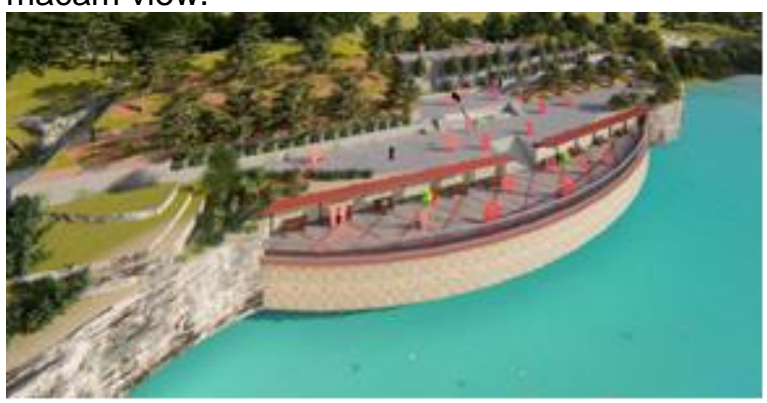

Gambar 8. View 1

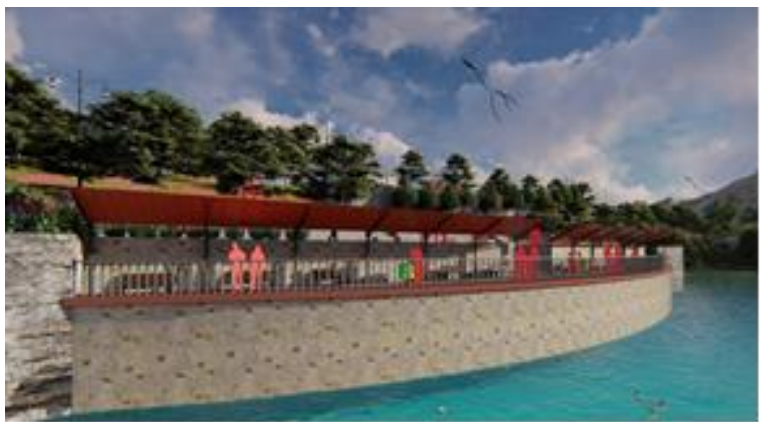

Gambar 9. View 2

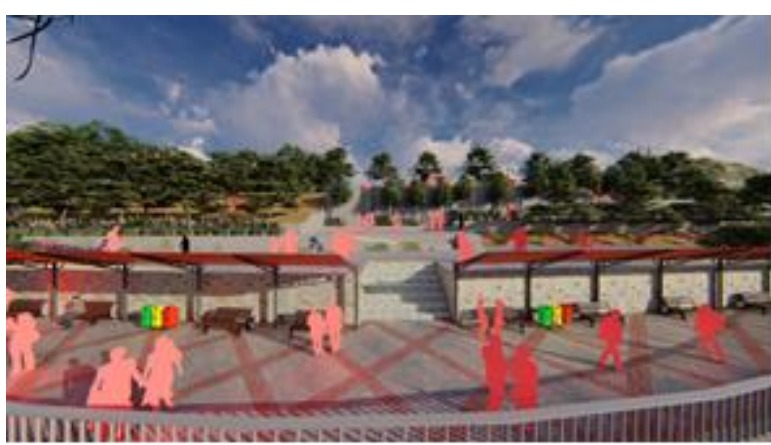

Gambar 10. View 3

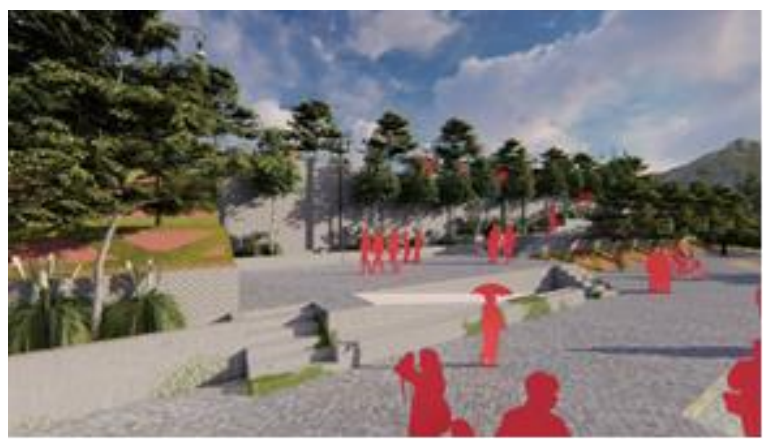

Gambar 11. View 4

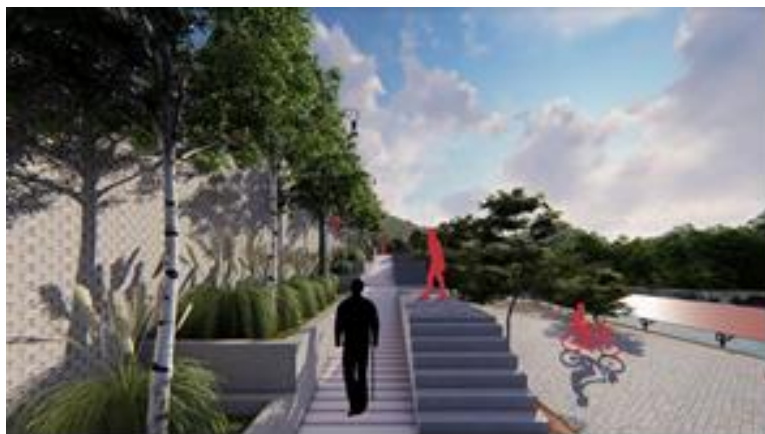

Gambar 12. View 5

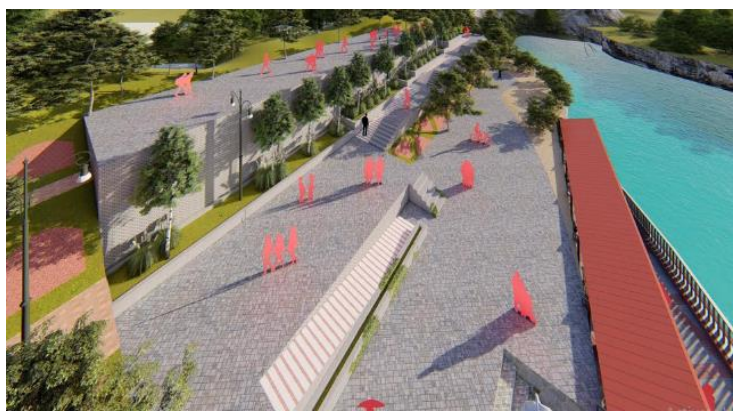

Gambar 13. View 6

\section{Sosialisasi}

Sosialisasi dokumen gambar rancangan dilakukan kepada perwakilan masyarakat Kampung Ekowisata Keranggan, yaitu kepada para pemuda Keranggan dan kepala pokdarwis (Kelompok Sadar Wisata).

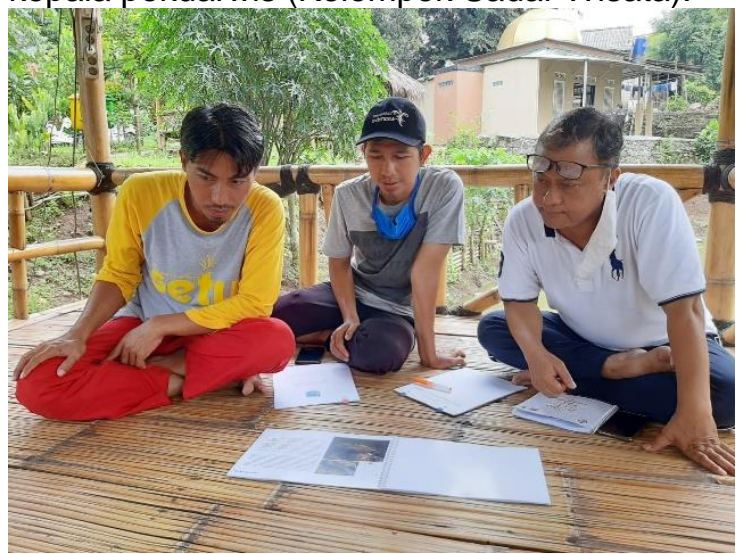

Gambar 14. Sosialisasi Dokumen Gambar Rancangan 
Tanggapan dari perwakilan masyarakat terhadap rancangan desain spot pemancingan dirasa sangat positif dan mengharapkan spot atraksi lain segera untuk didesain. Namun terdapat beberapa masukan yang perlu dipertimbangkan terkait desain spot atraksi lainnya yang akan didesain yaitu mengedepankan konsep alami, sehingga area serapan lebih banyak dibandingkan perkerasan.

Dokumen gambar rancangan spot pemancingan telah diterima oleh perwakilan masyarakat Kampung Ekowisata Keranggan dengan tanggapan positif, dan dapat menjadi masukan Dinas Pariwisata dalam pengembangan Kampung Ekowisata Keranggan.

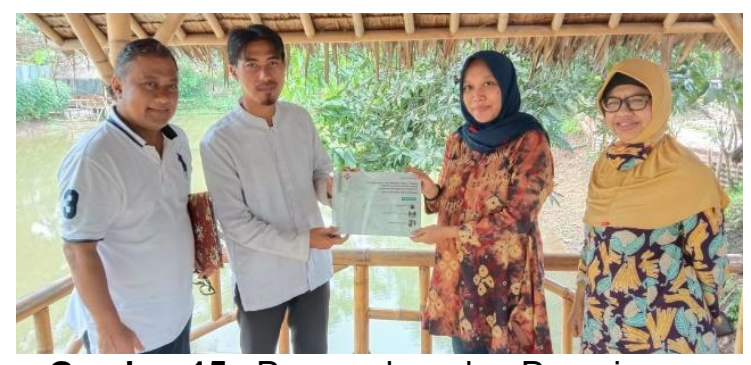

Gambar 15. Penyerahan dan Penerimaan Dokumen Gambar Rancangan

\section{SIMPULAN DAN SARAN}

\begin{tabular}{llr}
\multicolumn{2}{c}{ Kampung Keranggan } & telah \\
dicanangkan pemerintah & kota & sebagai \\
kampung ekowisata. & Perlu & adanya
\end{tabular} perencanaan dan perancangan infrastruktur guna mendukung Kampung Keranggan sebagai kampung ekowisata. Dinas Pariwisata telah memiliki perencanaan ekowisata Kampung Keranggan, namun masih secara umum dan belum sampai kepada tahap perancangan.

Spot pemancingan merupakan atraksi terpilih yang akan pertama kali dirancang. Alasan dari pemilihan spot pemancingan yaitu beberapa warga ada yang berprofesi sebagai nelayan, dan gemar memancing, selain itu area yang didesain merupakan wisata pemancingan sebelum banjir menerjang. Dikarenakan aktifitas memancing telah eksis dan fasilitas yang tersedia sangat minim, maka spot pemancingan layak untuk dirancang pertama kali.

Konsep yang digunakan dalam perancangan spot pemancingan yaitu mempertahankan keadaan eksisting. Kontur, bentuk tanah, dan vegetasi tidak banyak diubah guna mempertahankan karakter dari Kampung Keranggan.

\section{UCAPAN TERIMAKASIH}

Terima kasih diucapkan kepada Pusat
Riset Pengabdian Masyarakat (PRPM) Institut Teknologi Indonesia yang telah mendanai kegiatan abdimas ini.

\section{DAFTAR RUJUKAN}

Abdulhaji, S., \& Yusuf, I. S. (2016). Pengaruh Atraksi, Aksesibilitas, dan Fasilitas Terhadap Citra Objek Wisata Danau Tolire Besar di Kota Ternate. Jurnal Penelitian Humano, 7(2).

Amalina, D. (2017). Faktor yang Mempengaruhi Proses Pengambilan Keputusan Wisatawan Berkunjung ke Objek Wisata Religi Masjid Agung Islamic Centre Kabupaten Rokan Hulu. JOM FISIP, 6(2), 5-9.

Aryunda, H. (2011). Dampak Ekonomi Pengembangan Kawasan Ekowisata Kepulauan Seribu. Journal of Regional and City Planning, 22(1), 1. https://doi.org/10.5614/jpwk.2011.22.1. 1

Aulia, A. N., \& Hakim, L. (2017). Pengembangan Potensi Ekowisata Sungai Pekalen Atas, Desa Ranu Gedang, Kecamatan Tiris, Kabupaten Probolinggo. Jurnal Wilayah Dan Lingkungan, $\quad 5(3), \quad 156$. https://doi.org/10.14710/jwl.5.3.156167

Dinas Pariwisata Kota Tangerang Selatan. (2019). Kajian Ekowisata Kampung Keranggan / Dinas Pariwisata Kota Tangerang Selatan 1.

Hijriati, E., \& Mardiana, R. (2015). Pengaruh Ekowisata Berbasis Masyarakat Terhadap Perubahan Kondisi Ekologi, Sosial Dan Ekonomi Di Kampung Batusuhunan, Sukabumi. Sodality: Jurnal Sosiologi Pedesaan, 2(3), 146159.

https://doi.org/10.22500/sodality.v2i3.9 422

Khotimah, K., \& Wilopo, W. (2017). STRATEGI PENGEMBANGAN DESTINASI PARIWISATA BUDAYA (Studi Kasus pada Kawasan Situs Trowulan sebagai Pariwisata Budaya Unggulan di Kabupaten Mojokerto). Jurnal Administrasi Bisnis 51 Universitas Brawijaya, 42(1), 56-65.

Undang- Undang Republik Indonesia Nomor 10. Tahun2009 Tentang Kepariwisataan, (2009) (testimony of Presiden Republik Indonesia).

Vengesayi, S. (2003). a Conceptual Model of Tourism Destination Competitiveness and Attractiveness. Conceptual Papers / Marketing Theory Track, December, 637-647. 
http://anzmac.org/conference_archive/ 2003/papers/CON20_vengesayis.pdf

Wardhani, M. K. (2011). KAWASAN

KONSERVASI MANGROVE: SUATU POTENSI EKOWISATA Maulinna Kusumo Wardhani. Jurnal KELAUTAN, 4(1), 60-79. 